\title{
ロ腔一上顎洞瘦孔に対する新しい閉鎖術式の試み
}

伊藤輝 夫・原 博信・山口守

\section{A new technique for closure of the oroantral fistula}

Tcruo ITo $=$ Hironobu HARA $=$ Mamoru YamaguchI

緒 言

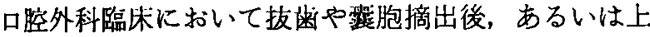
䯪洞炎根治手術後などに，しばしば臼歯部歯槽頂や口腔 前庭部に，口腔と上䋶洞との交通を招き，時としてそれ を閉鎖するに際し難泳することがある。

この oroantral fistula に対する閉鎖手術としては，従 来より Lautenchröger 法, 河西法, Budge 法, Kazanjian 法, Zange 法, Axhausen 法, Wasmund 法, Pichler 法など種々な方法が報告されているが，いずれ の方法も一長一短がある.

そこでわれわれは，これらの方法の欠点を補らべく， 口蓋粘膜下の結合組織を利用する方法を試み，現在をで に施行した13症例すべてに，きわめて良好な結果を得た ので，ここに本手術法の概要を報告する.

\section{臨床解剖と手術術式}

手術法は口蓋粘膜を full thickness で剥離したのち, 粘膜上層と下部結合組織層の 2 層に切離してつくられた 粘膜下結合組織弁を用いて瘦孔を閉鎖する方法である。

口蓋粘膜の surgical anatomy としては，正中部は薄 く, 歯槽突起にいくに従い厚さを增し，歯槽縁でも比較 的厚みがあり，しかも，主要血管は大口蓋動脈の分枝中 最大で，外側寄りにある前枝は，外口蓋溝を通り歯槽突 起底部にそって前走するため，この厚い部分の粘膜下結 合組織を有菱閉鎖弁として十分利用することができる （図 1，2）.

衍式の段階的説明は, 痤孔の位置と大きさの異なる代 表的な 3 症例を呈示し，それぞれについて述べる。

長崎大学医学部附属病院第 1 米科口腟外科（主任： 伊藤輝夫助教授)

First Department of Dent-Oral Surgery, Nagasaki University Hospital, Faculty of Medicine, The University of Nagasaki (Chief: Assist. Prof. Teruo Ito)

受付日：昭和53年 1 月 23 日

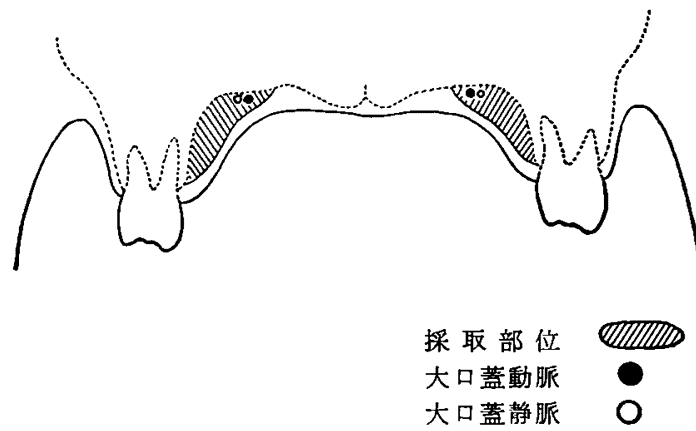

図 1 口蓋部の前額断面

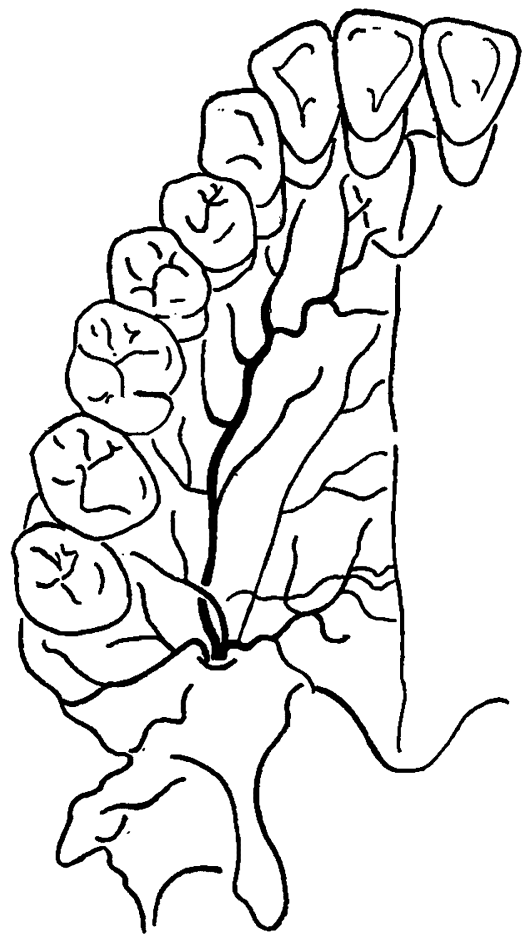

図 2 骨口蓋に分布する動脈の走向を示す 


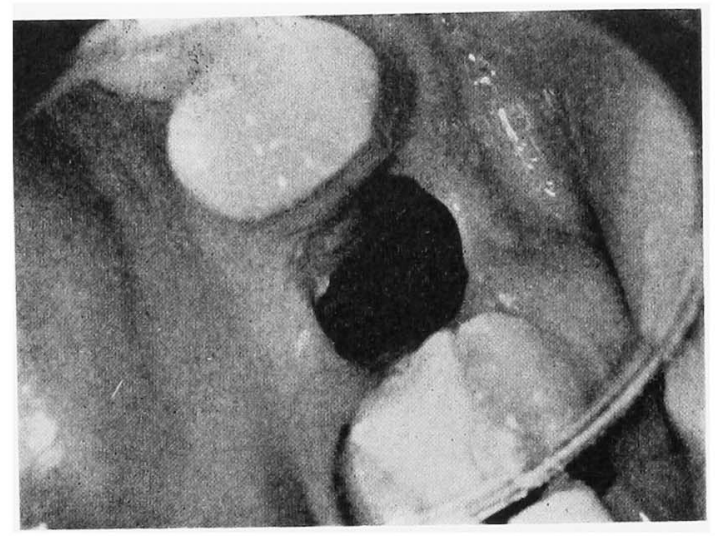

写真 1 症例 1 の| 6 部口腔一上類洞瘘孔を示す

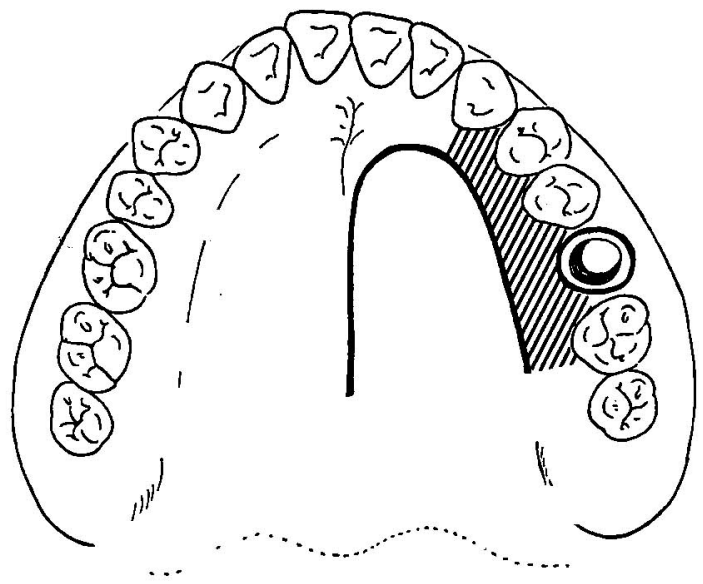

图 3 症例 1 の切開線

症例

\section{症例 1 (写真 1)}

22 歳男子で，上㴿洞内に迷入した $\mid \underline{6}$ 近心根拉よびロ 蓋根摘出後に潧孔を生したたのである。この症例に対し

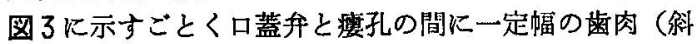
線で示す）を残すように切開線を設定する。すなわち， これは歯槽骨縁の壊死や歯肉退縮を予防する意味であ る. 次に瘦孔周囲を一部切除して新鮮創面をつくる。

口蓋弁を full thickness で制鹰したのち，粘膜上層と 下部の結合組織層の 2 層に切離して結合組織弁を形成す る（図 4)，その際，図1亿示したごとく正中部近くの 日蓋粘膜は薄く 2 層に圽榷することは容易ではないの で，通常，梂離された弁の歯槽側より $1 / 2 \sim 2 / 3$ の厚い 粘膜部を 2 層に切離し，大口蓋動脈を含んだ有茥結合組 織分（এ）を形成吉る。この升は弾性に䈏み，伸展属曲 できるため，弁の幅と長さを調整することにより籶槽頂 部怙よび口腔前庭側のかなりの大きさの瘦孔でる閉鎖す

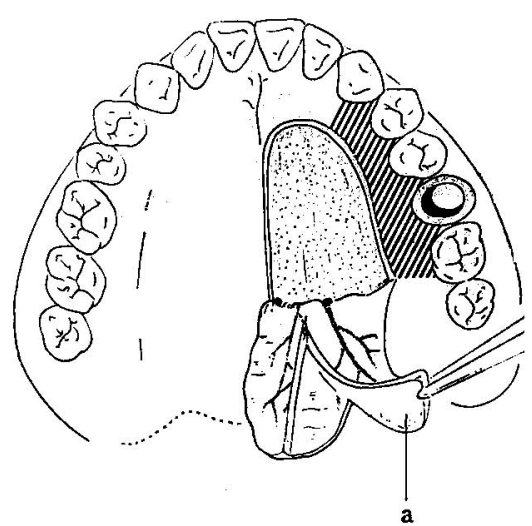

图 4 粘膜下結合組織升の形成

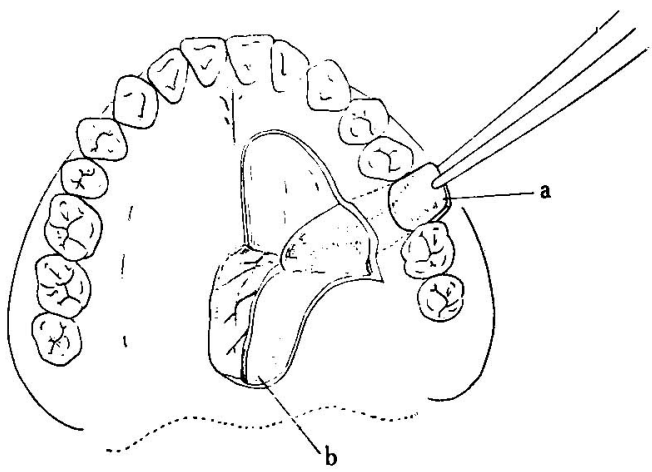

図 5 粘膜下結合組織弁による瘦孔の被覆

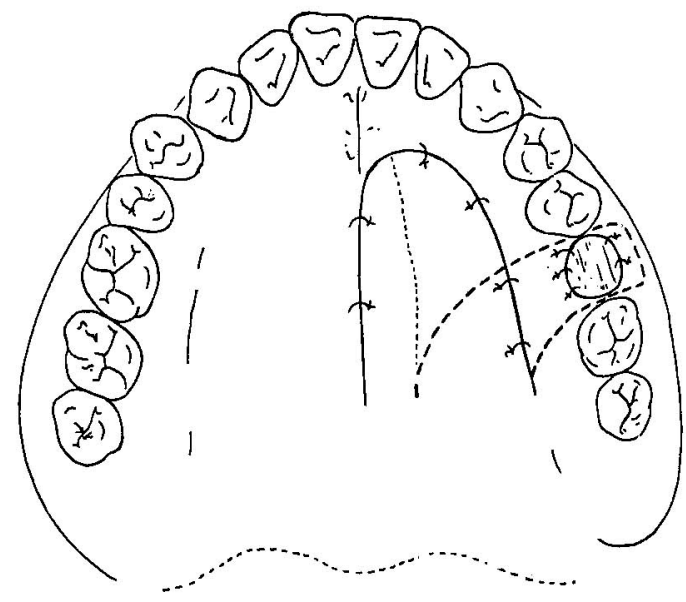

图 6 栈合終了

ることが可能である，つぎに口蓋升と㾇孔の間にある歯 肉 (斜線)を骨膜とともに䐣離举上して tissue bridge を作り，有茥結合組織弁（a）をその下から通し瘦孔上 へもってくる（図5）。こうすることにより閉鎖部位へ 


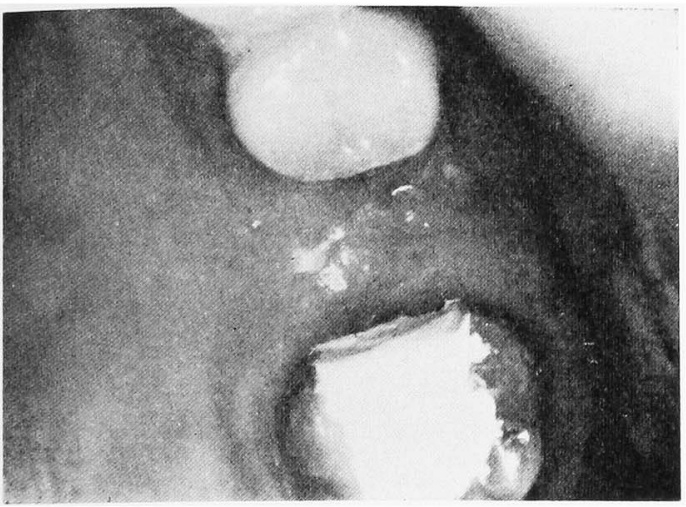

写真 2 症例 1 術後 1 か月目の所見, 瘦孔は閉銷 し，望ましい前庭が造成されている。

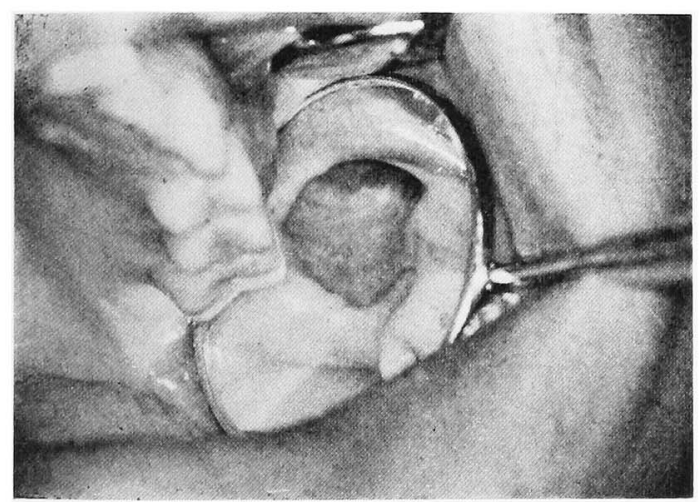

写真 3 症例 2 衍前所見

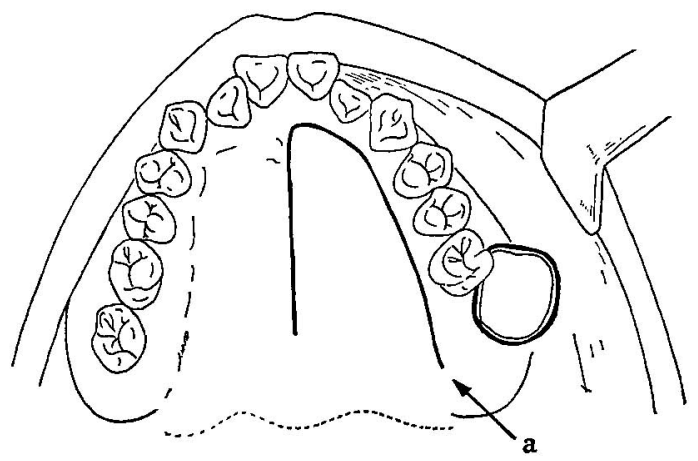

图 7 症例 2 の切關線

の血液供給をより確保することができ，また弁の過緊張 を防ぎ，定位置での安定した固定を得ることができる．

縫合に際しては，受容侧の付着函肉が厚い場合は割切 を入れて有茎弁と接合させ，また粦槽粘膜では骨膜下に 手（a）の先を押し込むようにして縫合する．䂝された 供給側升（b）は図 6 に示すごとく定位置に戻し縫合す

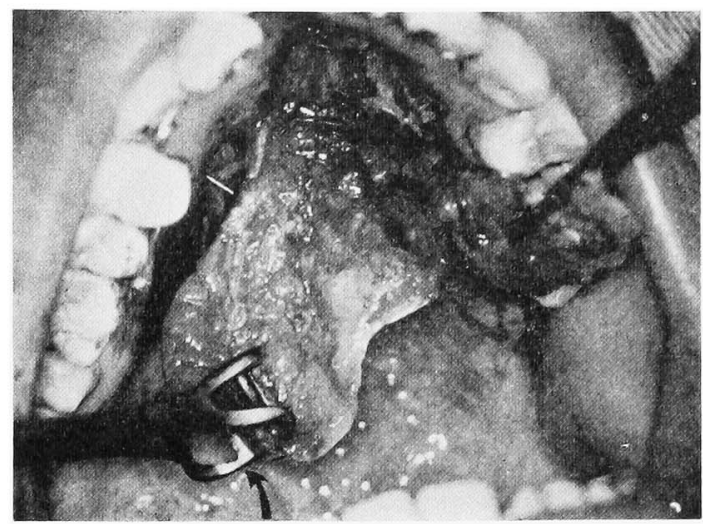

写真 4 粘膜下結合組織弁の形成（失印はバブュッ クの靯組織把持鉗子)

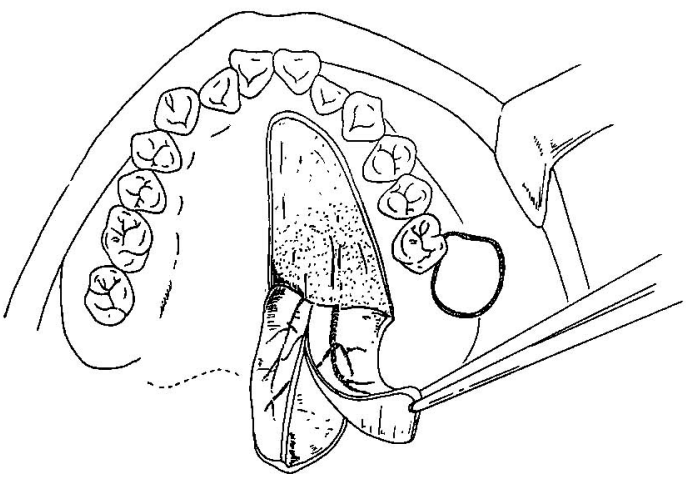

図 8 粘膜下結合組稢弁の形成

る。したがって供給側の骨面は簬出することはない，縫 合終了ののちに創面の安栺と保護のためセルロイド休副 子を装着し，術後約 7 日目に除去する。

術後 $1 \sim 2$ 週目の移植部は安定した創傷治渝を示し， 1 か月目には完全に上皮化され，供給側および受容側の 治癒過程に異常を認めることはない（写真 2).

\section{症例 2（写真3）}

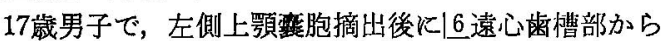
口腔前庭部にかけて直径 $2.0 \mathrm{~cm} \times 1.5 \mathrm{~cm}$ の瘦孔を生じ たるのである，この症例は瘦孔の位直が供給側と隔たり があり，また比較的大きな組織欠損であるところから， 適切な長さと幅をもった有茎結合組織弁の形成のため十 分余裕をむった切開線を設定する必要がある（図 7).

術式については症例 1 で説明したと同様に口蓋弁を

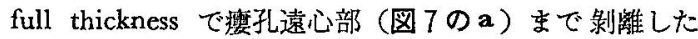
のち、この弁を血管損傷のないように上皮層と結合組織 層の 2 層に切䧻する（写真 4, 図 8)。しかし, この上 らに長くかつ薄い一定幅の結合組織弁をもとめる際には バブコックの軟組織把持錐子を.手に使いながら升の㨒 れが生じないよらに注意しなければならない，そして写 


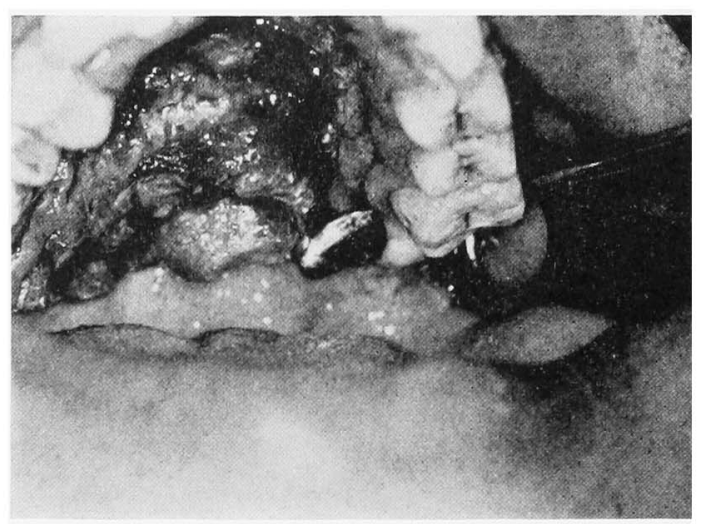

写真 5 tissue bridge の形成

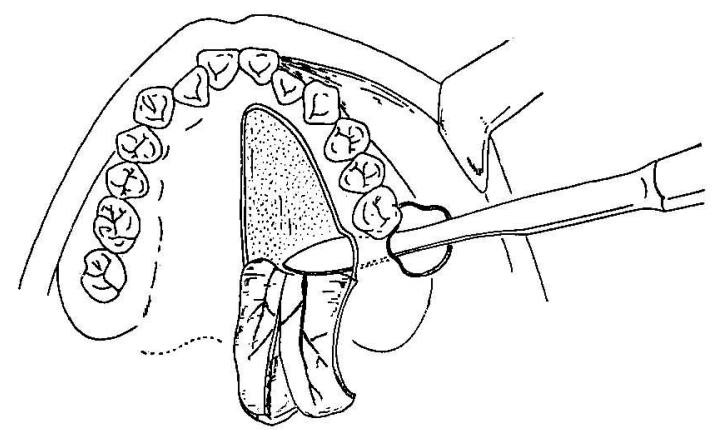

図 9 tissue bridge の北成

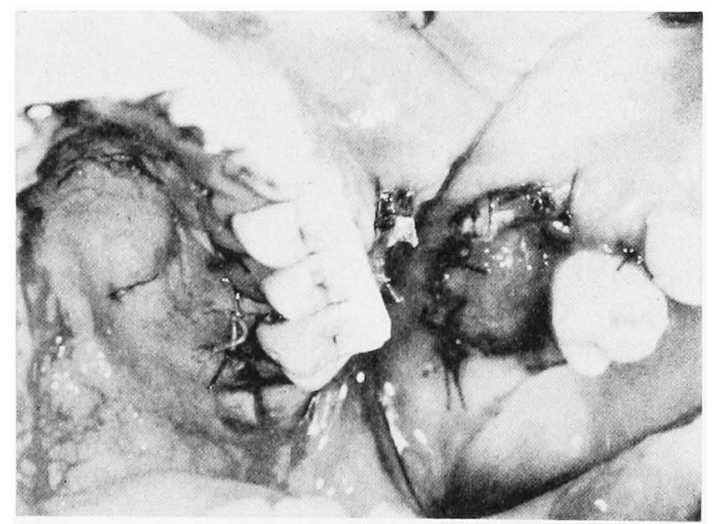

写真 7 䋖合終了時の供給側と受容倒を示す

真5，図9に示したごとく tissue bridge を作り，弁を $90^{\circ}$ 回転させて写真 6 , 图 $100 こ ゙ と く$ 瘦孔上へ有茥結合 組織弁をもっていき被覆する，写真 7 は供給侧拈よび受 容側の縫合を示したものである。また図11は猡孔閉鎖部 位の前額断の檔式図であり，a有茥結合組織升， b は 畨肉, ↔は煩粘膜である. 術後, 症例 1 と同様にセル口

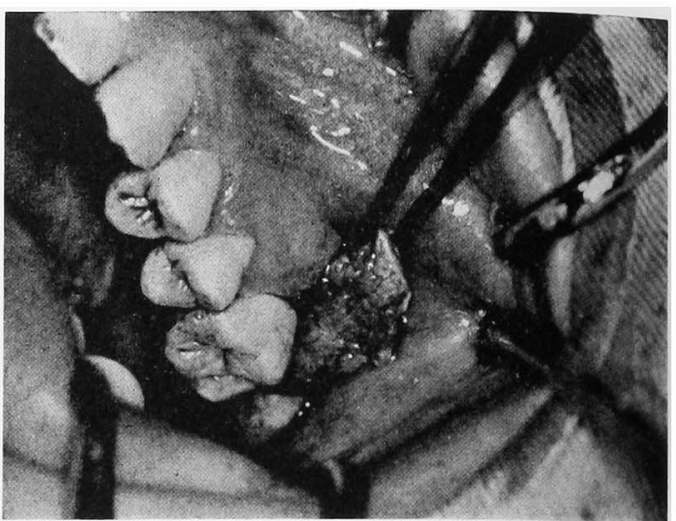

写真 6 粘膜下結合組織手による瘦孔の被覆

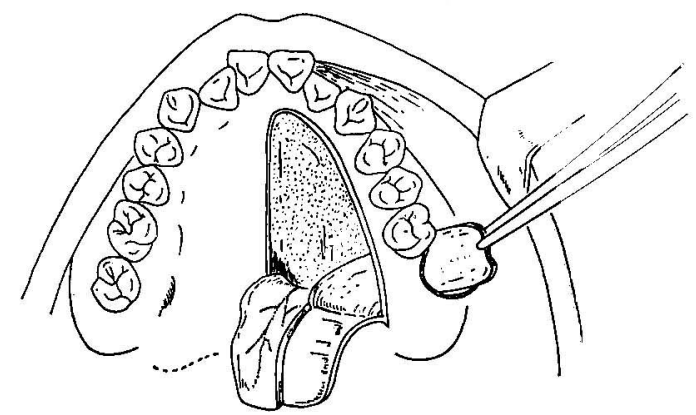

図 10 粘膜下結合組織弁に上る瘦孔の被覆

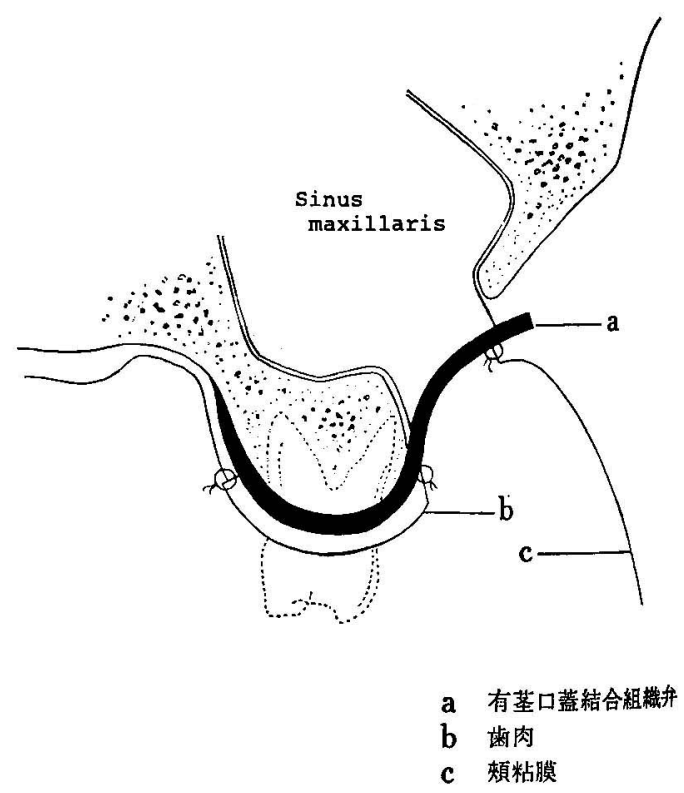

図 11 瘦孔閉銧部の前額断 


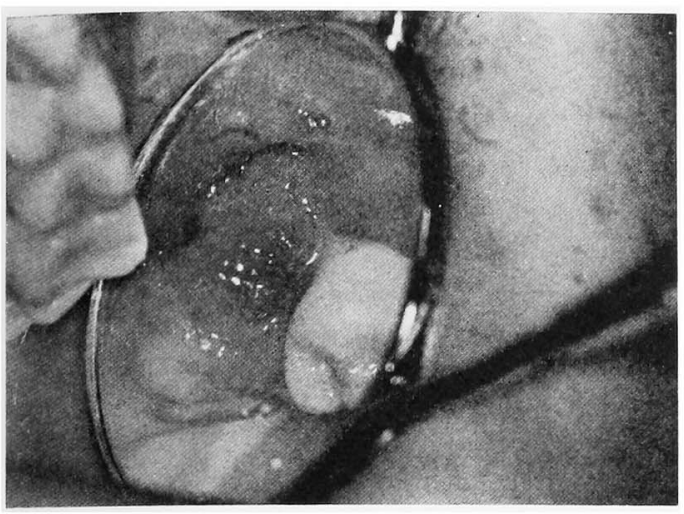

写真 8 症例 2 の術後 2 週間目の所見

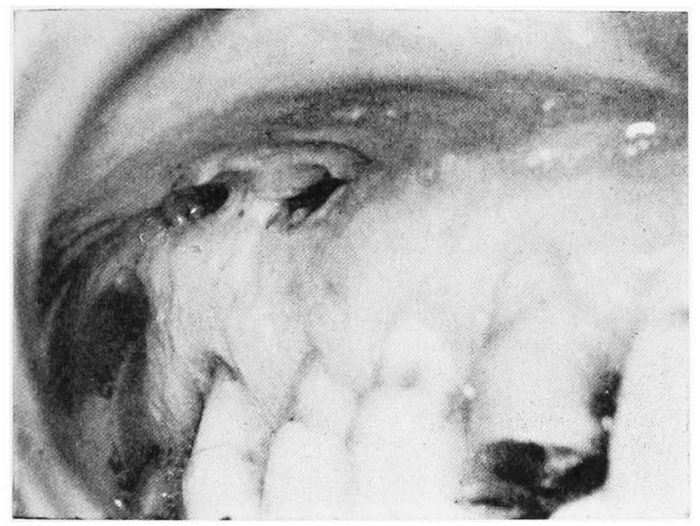

写真 9 症例 3 の郝前所見

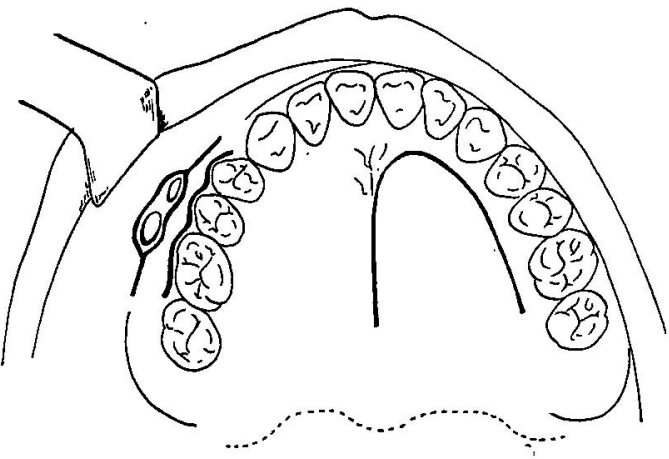

図 12 症例 3 の切開線

イド休副子を用いて創面の保謢および固定を行った。

写真 8 は術後 2 週間目のbので，やや発赤を認める 良好な生着状態を示し瘦孔は完全に閉鎖されている。

症例 3 (写真 9)

50 歳男子で，右側上顎洞炎根治手術後に76 65 前庭歯 槽部に 2 個所の瘻孔を生じたものである、この症例は当

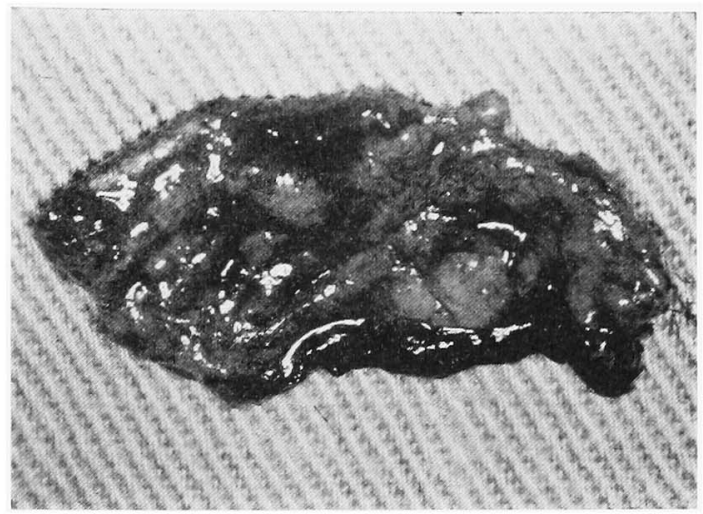

写真 10 棌取された粘膜下結合組裁

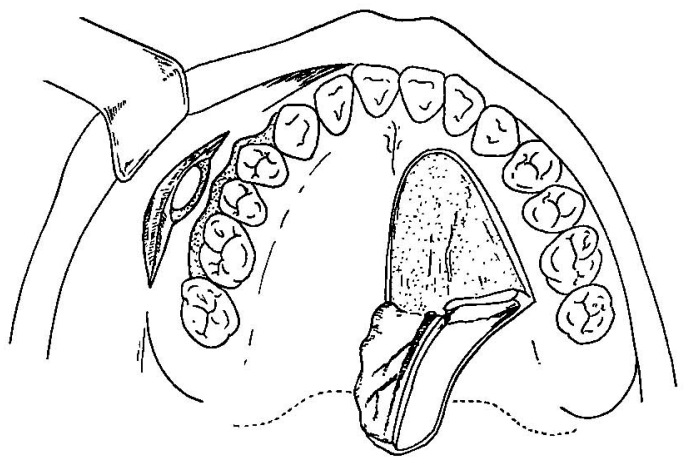

図 13 採取した粘膜下結合組緫

該部に歯牙の欠損がないため症例 1，2で用いた有茥弁 を応用することが不可能であるため，遊離移植升として 口监粘膜下の結合組織を用いる方法を行った。

供給側の切開線（図12）乹よび口蓋粘膜を 2 層に切離 する操作は前に述べた 2 症例と同様であるが，写真10, 図13に示すごとく適当量の結合組織片を採取する。採取 された弁を瘦孔部（受容側）に置く際，弁の㹉れを予防 し，操作を容易にするため遊離移植弁の両端に縫合系を 通しておく，それから，瘦孔部橉慒侧の㴹肉骨膜弁を剥 離挙上して写真11K示すごとく tissue bridgeをつくり, その遊離結合組織弁をその下に㨀入し，図14に示すごと く瘦孔を閉鎖縫合する，次に先ほどの移植弁に通した 2

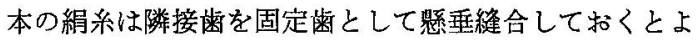
い. 術後の創偒保謢には前症例と同じくセルロイド床副 子を用いた。

写真12は術後 1 か月目のものであるが瘦孔部は完全に 


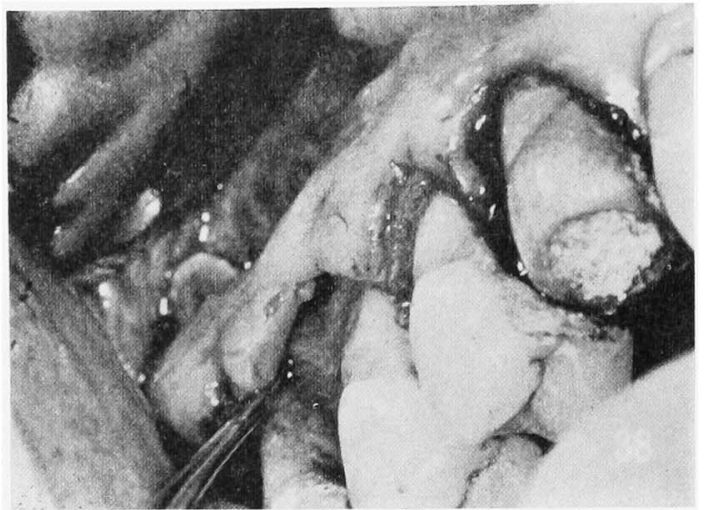

写真 11 tissue bridge の形成

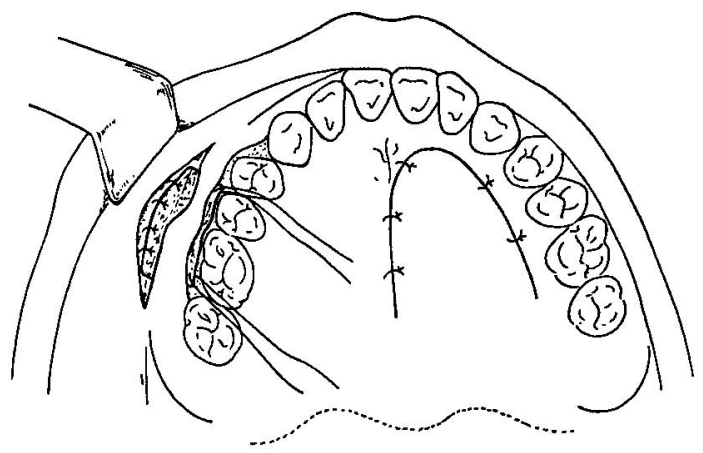

図 14 遊離粘膜下結合組織による喥孔の被覆 を示す

閉鎖されており，口腔前庭の深さも望ましい状態で維持 されている。

考察

Oroantral fistula の羽鎖法には前述のごとく多くの術 式があるが，いずれる一長一短である，骨势を用いる Lautenchröger 法では，隣接粦根を露出させずに歯槽か ら一定の厚い骨手を有茎骨折させることが困難であり， 通常その骨弁は小片に分離してしまい，その結果穿孔は 以前にもまして大きくなる危険性を有している。

河西 ${ }^{1)}$, 河合ら ${ }^{2}$ の推奖する自家骨移植による閉鎖法

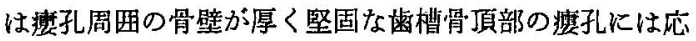
用しらるが，口腔前庭部の周囲骨の䔦い瘦孔に対しては 好結果を得がたいように思われる。.Budge ${ }^{3)}$ は組織火損 部をゴールドプレート，タンタルムプレート，タンタル ムメッシュガーゼなどの非生物物質で閉鎖した症例を報 告しているが，この方法は二次的にこれらを取り出さな ければならない繁稚さがあり，また三浦いの推䍃する obturatorを用いる方法は，即洔閉鎖の目的には夷施す ることができない。

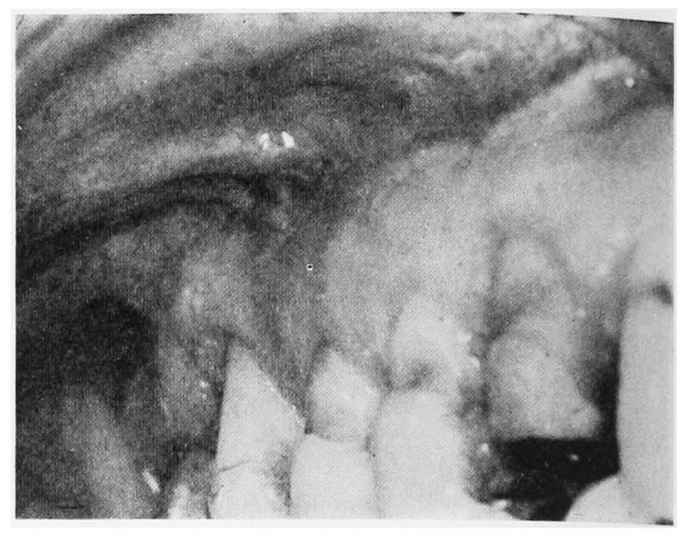

写真 12 症例 3 の得後 1 か月目の所見

一方, 口腔軟組織の sliding ないし rotation flap K よる閉鎖法も種々推奖されている.なかでる架橋弁を用 いる Kazanjian 法は有略䫟には使用できず, 供給側に 骨面の露出を生ずるなどの久点があり, 辺縁弁を用いる Zange 法は比較的簡単であるが，乙の政の繾合線は骨 久損部に位䁂することが多いため，㓣面が陊開し中すく 好結果を得ることはまれである。頓側有茎升を用いる Axhausen 法や Wassmund 法では, 頓弁にかなりの伸 展性があるため創縁の接合が容易で，骨への影響がな い. しかし，その反面，煩側粘膜は薄く開口運動飞よる 影響を受けて㲤引されやすいため，術後において口腚前 庭が浅くなり，口腔環境の悪化を招き，将来義歯作製上 の障害を生じることになる，また煩部にはステノン氏管 乳頭部が存在するため, 保護的に行ら必要があり, 加党 て煩側有茥弁は主要血管を有しないため弁形成に際して は, 弁の幅と長さの比や厚さをよく検討しなければなら ない、このよらなことから煩部からの弁形成は少なから ず制約をらけることになる。

一方，口蓋有茥弁を用いる Pichler 法は動静脈を口葢 粘膜弁のなかに含み，升の栄養が高度に保証されるから 安全であり，前莛粘膜に影㗽を与えることすない，しか も，開口運動による影響を受けないので縫合部が将開す る恐れがないなどの理由により，口蓋を供給側とする手 術方法が諸家によって好んで応用されている。

1974 年 Nicholas ${ }^{5)}$ は前記した口蓋粘膜を供給側とし た方法に改良を扣光，口蓋弁の定位置での確実な固定，

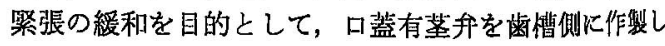
た tissue bridge の下を通し瘦孔上へるってくる方法を 郝告している，この方法の問題点としては，升を回転し て敕合した際，屈曲部に dog ear とよばれる隆起が生 し，また瘦孔の位置によっては年に限界をきたすばかり でなく供給侧に骨面の露出を生ずるなどの難点がある， 同じく1974年，高㤯6)は硬口盐粘膜の island flap を用い る方法を報告しているが，この方法は dog ear が生じ 
ない点で好ましい方法である。しかし供給側の骨面露出 は少なからず存在し, かつ口腔前庭部への応用は困難で あると思われる。

以上，諸家により報告された手術法の問題点を指摘し たが，今回のわれわれが考案した口蓋粘膜下の結合組織 升を利用する閉鎖方法は，歯槽頂および口腔前庭に生じ た組織欠損に応用することができ，しかも，この結合組 織弁は血行および伸展性富み，厚い上皮組織を含まな いので，全層口蓋有茥弁法のように屈曲部に dog ear を 作らず，弁を重複させて利用することもでき，定位置で 安定した固定ができるので過祭張を防ぐことができる.

また，供給側口蓋上皮層は元の位膡に戻すため，供給側 骨面の露出がなく，前庭側では付着歯肉の幅を適度に保 つことができるなど，患者にとっても不快感が少なく， 創部の治瘾が早く，審美的障害を残さない．

なお，痽孔閉鎖のため口蓋から有茥弁が直接応用でき ない症例，すなわち 欠損歯を伴わない瘦孔が存在する 場合は遊離結合組織移植弁としても利用できるなど, 種々利点を有することから，口蓋の粘膜下結 合組織は oroantral fistula を閉鎖するに際し，最も安全で確実な 供給弁となりらると考劣る。

なお，本手術法は従来の術式に比べて，移植弁の取り 扱いが難しいよらに思われるが, surgical anatomyを十 分脳裏に描いて行えば，口蓋全層弁を上皮層と下部結合 組織層の 2 つに切離することは，さして困難ではない。 しかし，ときとして口蓋粘膜の薄い症例や長く藻い一定 幅の升を求める際には慎重な手術操作が必要である。

\section{結語}

1. われわれは，口腔一上顎洞揾孔に対し，口蓋粘膜 下の結合組織を用いて閉鎖する乎術術式を考案した。

2. 本報告で口腔一上靧洞瘦孔の代表的な 3 症例を示 し，それらに対する手術術式を段階的に概説した。

3. 本術式を現在まで 13 症例に応用した結果, 適応範 囲が広く, 効果が確実であり, 従来の閉鎖手術に比べ て，きわめて有效な方法と考えられた。

なお，本論文の要旨は昭和 52 年 2 月 19 日, 第30回日本 口腰外科学会九州地方部会（能本）扰よび昭和 52 年 10 月
23日，第22回日本口腔外科学会総会（東京）に打いて発 表した。

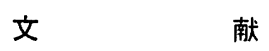

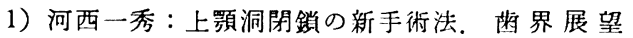
12, 11: 4071955.

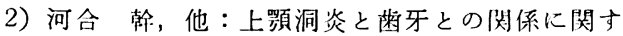
万研究, 特に菌性上顎洞炎手術時の婘牙抜去窝 の自家小骨片移植閉鎖について（追補）。只外 誌 3: 541957.

3) Budge, C.T.: Closure of an antraoral opening by use of the tantalum plate. J Oral Surg 10: 321952 .

4) 三浦真一：上顎洞楼槽瘦孔と副鬼腔炎。口病誌 2: 21953.

5) Nicholas, C.C.. Modified palatal flap technique for closure of oroantral fistulas. J Oral Surg 32: 1121974.

6) 高橋庄二郎：顎顔面外科の現況。岿科学報 74 : 9911974.

7) 上條雍彦：口腔解剖学. 3, 脈管学, アナトー 么社, 東京, 1970,506 頁.

8）朝倉昭人：歯性上顎洞炎と上顎洞口腔膺の処置. 菡界展望 37, 1：71 1968.

9）朝倉昭人：洞内迷入蔽牙の摘出法々上顎洞菻梢 瘦の処置について。俻科時報 7:24 1970.

10）上佟寉彦，他：合成樹脂鋳型標本に上万眼窝下 動脈, 口莣動脈の研究。萄科学報 60:201960.

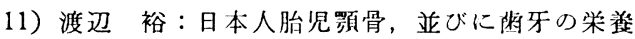

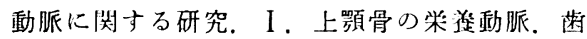
科学報 63：53 1963.

12）堀口伸作：绦性上枵洞炎。口外誌 3：3 1957.

13）渡辺義男：上顎洞穿孔について（1）。菌界展望 10: 3381953.

14）渡扨義男：上顎洞学孔について（2）。蔽界展望 10: 6491953.

15) Norman, S.S. and Phillip, L.M.: Fenestrated palatal mucosal grafts for vestibuloplasty. J Oral Surg 37: 341975.

16) William, C.B. and Edward, J.T.: Free autogenous connective tissue grafting. J Priodontal 47: 5801976. 